\title{
Kur ve Bankacılık Krizlerine Bankaların Çekirdek Dışı Yükümlülüklerinin Etkisi, Kırılgan Beşli Üzerine Araştırma ${ }^{1}$
}

\begin{tabular}{|c|c|}
\hline \multicolumn{2}{|c|}{ Gülçin KAZAZ ${ }^{2}$} \\
\hline$\frac{\text { Gönderim Tarihi }}{25.07 .2021}$ & $\frac{\text { Kabul Tarihi }}{19.11 .2021}$ \\
\hline
\end{tabular}

\section{Önerilen Atıf / Suggested Citation:}

Kazaz, G. (2022). Kur ve Bankacılık Krizlerine Bankaların Çekirdek Dışı Yükümlülüklerinin Etkisi, Kırılgan Beşli Üzerine Araştırma. Bankacılık ve Finansal Araştırmalar Dergisi, 9(1), 20-42.

$$
\ddot{O}_{z}
$$

Türk bankacıllk sektörünün çekirdek dışı yükümlülükleri 2012 yllından itibaren artış kaydederken, Kredi/ GSYIH açı̆̆ yükselerek genel trendden ayrılmakta, kârlılıkta azalma, tahsili gecikmiş alacaklarda artış, reel sektörde yüksek borçlanma görülmektedir. Çalışma, Türk bankacıllk sektöründe çekirdek dlşı yükümlülüklerde gözlemlenen artışı, Türkiye'nin de yer aldı̆ğl Kırılgan Beşli olarak tanımlanan ülkeler açısından incelemektedir. Kırllgan beşli ülkelerindeki çekirdek dışı yükümlü̈lük artışının bankacıllk ve kur krizlerine olan etkisini, panel veri modeli ile 2011-2019 yllarını kapsayan bir örnekleme dayandırarak araştırmaktadır. En önemli bulgu, çekirdek dlşı yükümlülükler deki artışın kur ve bankacıllk krizlerine olan pozitif etkisinin belirlenmesidir. Çekirdek dışı yükümlülüklerin GSYIH oranı, bankaların çekirdek yükümlülüklerinden fazla borçlanmasının, ekonomiye olan etkisini anlamamıza da yardımcı olmaktadır.

Anahtar Kelimeler: Banka Çekirdek Yükümlülükleri, Çekirdek Dışı Yükümlülükleri, Finansal Kriz, Kur Krizi, Bankacılık Krizi

Jel Kodları: E44, F34, G21

\section{Banks Non-Core Liabilities Effects on Banking and Currency Crisis a Research on Among Fragile Five}

\begin{abstract}
The non-core liabilities in the Turkish banking system have tended to increase since 2012. The growing credit gap differs from the general trend, the profitability decreases, the non-performing loans gradually increase and high borrowing occurs in the real sector. Based on this evidence, our study deals with the effects of non-core liabilities over the stability of the Turkish banking sector as a crisis dynamic. The research has been based on extensive samples covering 2011 to 2019 employing the panel data model and it is showing the effect of the increase in non-core liabilities over banking and exchange rate crisis among the so called Fragile Five Countries including Turkey. The key finding is the definition for the positive impact of the increase in non-core liabilities upon the banking and exchange rate crisis. The non-core liabilities to GDP ratio also helps us to overview how the bank debts affect the economic situation when they exceed their core-liabilities.
\end{abstract}

Keywords: Core Liabilities, None-Core Liabilities, Banking Crisis, Banking Solvency, Currency Crisis

Jel Codes: E44, F34, G21

\footnotetext{
${ }^{1}$ Bu çalışma Marmara Üniversitesi Bankacılık ve Sigortacılık Enstitüsü Doktora Programında, Prof. Dr. K. Batu Tunay tarafından yürütülen doktora tezinden üretilmiştir.

${ }^{2}$ Marmara Üniversitesi Bankacılık ve Sigortacılık Enstitüsü, rose.kazaz@gmail.com, https://orcid.org/0000-0003-

$1430-3734$
} 


\section{Giriş}

Kredi/GSYİH oranı ile bu oranın uzun vadeli eğilimi arasındaki fark olarak tanımlanan kredi GSYİH açı̆̆ı, finansal piyasaların yükseliş dönemlerinde, sermaye oranını artırarak bankaları finansal krizlere karşı korumayı hedeflemektedir. Drehmann ve Tsatsaronis (2014), rasyoyu bu açıdan finansal krize karşı yumuşatıcı bir etki yaratsa da mevcut krizle mücadele konusunda yapıcılığ 1 bulunmadığ 1 konusunda eleştirmektedir. Diğer taraftan her kurumun, likit olma durumu, verilen kredilerin teminatlandırılması, açık pozisyon büyüklüğü, borçlarını ödeme kabiliyeti gibi finansal yapılarındaki farklılıklar ayrı ayrı gözetilmemekte, genel bir yaklaşım takip edilmektedir. $\mathrm{Bu}$ açılardan çekirdek dışı yükümlülük (ÇDY) analizi ile bankacılık sektörünün anlık finansal durumunun tespit edilebilmesi, gerekli önlemleri saptamada daha kullanışlı bir veri seti oluşturabilir.

Bazı ekonomistler krizlerin nedenlerine dair çalışmalarında, bankaların çekirdek dışı fonlamalarındaki yükselişin finansal krizlere ilişkin güçlü bir gösterge olarak dikkatle takip edilmesi gerektiğini savunmaktadır. Bankacılık düzenleme kurumları da küresel krizden sonra bankaların borçlanma ve vade uyumlarının yanı sıra çekirdek ve çekirdek dışı yapılarını da dikkate almaya başlamıştır. Shin vd. (2012), mevduatı ticari bankaların ana fonlama kalemini oluşturması ve yenilenme riski açısından alternatiflerine göre daha istikrarlı olması nedeniyle özkaynaklarla birlikte çekirdek yükümlülük, repo, bankalara borçlar, tahvil ihracı gibi yurt içinden sağlanan fonlar ile menkul kıymet ihraçları, doğrudan borçlanma, dış ticaretin finansmanı, sendikasyon kredileri gibi yurt dışı kaynaklardan sağlanan fonları da çekirdek dışı yükümlülükler olarak tanımlamaktadır. Kısaca bankaların mevduat hesaplarını çekirdek (core liabilities) yükümlülükler, bankacılık sektörünün diğer kaynaklardan borçlanmalarını da çekirdek dışı (noncore liabilities) yükümlülükler olarak sınıflandırırsak, çekirdek dışı yükümlülüklerin GSYİH'ya oranı, ekonomideki kredi büyümesinin göstergesi olabilir. Yüksek kredi artışları cari işlemlerdeki dengesizliklerle birlikte gerçekleşmekte ve finansal krizlerin tahmininde güçlü bir sinyal niteliği taşımaktadır.

Mendoza ve Terrones (2012), gelişmekte olan ekonomilerde kredi genişlemelerinin finansal reformlar ve üretim artışları sonucunda olmadığını, büyük sermaye girişlerini takiben arttığını, gelişmiş ekonomilerde ise finansal reformlar ve üretim artışlarının ardından kredi genişlemelerinin olduğunu ve büyük sermaye girişlerinden sonra azaldığını belirlemişlerdir. Schularick ve Taylor (2012), tarafindan yapılan çalışma, son 5 yılda gerçekleşen hızlı kredi büyümesinin, parasal göstergelere göre finansal kriz olasılığını artırdığını tespit etmektedir.

Tüm bu tespit ve değerlendirmelerin ışı̆̆ında ÇDY'deki artışın bankacılık ve kur krizlerine olan etkisi, panel veri modeli kullanılarak, Kırılgan Beşli ülkelerini kapsayan bir çalışmaya dayandırılmış ve kuvvetli ilişki saptanmıştır. ÇDY ölçümlenmesi kolay, güçlü bir veri seti olması, sistemik riskin öncü göstergesi olarak kabul edilen (kredi/GSYİH) kredi açı̆̆ 1 hesaplamasından farklı olarak, kredi döngüsü yerine, finansal döngüyü (ÇDY/GSYİH) baz almakta ve firma bazında borçlanmanın neden olduğu sermaye açığının hesaplanmasına imkân vermektedir. Sermaye açı̆̆ı hesaplaması; kriz döneminde ihtiyaç duyulan sermaye tutarıdır.

\section{Uluslararası Çalışmalarda Çekirdek ve Çekirdek Dışı Yükümlülükler}

2008 krizinden beri gelişmiş ülkelerin büyük bir kısmı ekonomik daralmadan çıkıp büyüme sağlayamamış ve durgunluğa maruz kalmışlardır. Buna karşın gelişmekte olan ve yükselen ekonomilerin büyük bir kısmında hızlı bir büyüme gerçekleştirilmiştir. 1990-2000 yılları arasında, gelişmekte olan ülkelerin gelişmiş ülkelere göre ulaştıkları büyüme farkı 1-1,5 puan kadar fazla iken, 2000-2008 döneminde fark açılarak 5 puana kadar yükselmiştir. 2008 sonrasında ortalama \%3 oranında büyüme göstermişlerdir. Akyüz (2017), "Krizle birlikte faiz oranları, yükselen ekonomilerde de genellikle aşağı çekilmiş ve bu hızlanan sermaye girişleri ile birlikte 
kredi varlık ve döviz piyasalarında yeni balonlar yaratmıştır" şeklindeki tespiti yaşanan finansal gelişmeleri özetlemektedir.

Shin vd. (2012), finansal döngünün ve finansal kuruluşların hassasiyetini anlamak için kullanılabilecek öncü bir gösterge olduğunu söylemektedirler. Kore bankacılık sektörü üzerinde çalışarak, bankaların risk alma konusundaki davranışları ile büyüyen çekirdek dışı borçlanma arasındaki ilişkiyi ortaya koymaktadırlar. Çekirdek dışı yurt dışı borcun ve nihayetinde toplam bankacılık borçlarındaki artışın oynaklığı artırması, faiz oranlarında da artışa neden olarak Won'da değer kaybına neden olduğu ve bu nedenlerle çekirdek dışı yükümlülüklerin GSYİH'ya oranının, ekonominin işleyişini anlamak için iyi bir ölçü olabileceğinden bahsetmektedirler. Bankacılık sektörünün sağlamlığı, yabancı fonların ekonomiye aktarılmasında önemli bir rol oynamaktadır. Banka bilançolarında meydana gelecek zincirleme bozukluklar ise; sistemik çöküşe neden olabilecektir. Bu nedenle ilave düzenlemelere ihtiyaç duyulmakta ve merkez bankaları geleneksel fiyat istikrarını sağlama görevlerinin yanında finansal istikrarı da sağlayacak yeni düzenlemeler üzerine yoğunlaşmaktadırlar.

Bankaların yurt dışına olan borçları çekirdek dışı fonlamanın önemli bir kısmını oluşturmakta ve hızlı kredi büyümesine kaynak teşkil etmektedir. Krizlerin nedenlerini araştıran çalışmalar, oynaklık, likidite krizi, dış borç büyümesi, kısa süreli borçlanma, ülke rezervleri gibi değişkenleri incelemişler, bankacılık sektörünün etkisini önemli bir etken olarak çalışmamıştır. Hahm vd., (2012), bankaların çekirdek dışı borçlanmalarını şartlı değişken olarak seçtikleri panel probit metodunu kullanarak gelişmekte olan ülke krizlerini araştırmışlar ve çekirdek dışı borçlanma büyüklügünün, döviz ve bankacılık krizi ile güçlü bir etki içinde olduğunu ancak borsa ile aynı etkileşimi göstermediğini tespit etmişlerdir. Basel III bankacılık düzenlemesinde, Basel komitesi (BCBS) döngüsel sermaye kalkanı gereği üzerine kural getirerek, bankaların sermaye artışı ihtiyaçlarını saptamada kredi/GSYIH rasyosunu kullanmakta olsalar da Hahm vd. (2012), kredi/GSYIHH rasyosunun çekirdek dışı borçlanma oranına göre zayıf bir gösterge olduğunu ve verilerin yayınlanma sıklığının gecikmelere neden olabileceğini savunmaktadır. Krugman (2009), Bernanke (2009), Didier vd. (2011), ve daha birçok ekonomist, gelişmiş ve gelişmekte olan ülkelerin krize girme nedenleri, krizlerin neden olduğu benzer ve farklı ekonomik etkiler üzerine birçok çalışma yapmıştır. Gourinchas ve Obstfeld (2012), 1973-2010 yılları arasındaki verileri kullanarak gelişmiş ve gelişmekte olan ekonomilerin finansal krize girme nedenlerini incelemişler ve ülke kurundaki değerlenmenin, kaldıraç oranlarında ve oynaklıktaki artışın krizi açıklayan en önemli değişkenler olduğu sonucuna ulaşmışlardır.

Frankel ve Rose (2000), 100 gelişmiş ülke üzerinde 1971-1992 yılları arasında yaptıkları araştırmada, ülke içi kredi büyümesinin yüksek, ülke büyümesinin düşük, yurt dişı faiz oranlarının yüksek ve doğrudan ülkeye yapılan yatırımların borçlanmaya düşük bir oran gösterdiği durumda döviz krizinin oluştuğundan bahsetmektedir. Gelişmekte olan ülkelerde para ve bankacılık krizlerinin birlikte ortaya çıtığı ikiz krizler gözlenmektedir. İkiz krizlerin 1980 sonrası finansal serbestleşmenin başladığı dönemde artış göstermesi, finansal serbestleşmenin ikiz krizlerin nedeni olduğunu düşündürmektedir. Kaminsky ve Reinhart (1999),1970-1979 döneminde 26 para krizi, 3 bankacılık krizi tespit etmelerine karşın, 1980-1990 yıllarını kapsayan dönemde 50 para krizi, 23 bankacılık krizi ve 18 ülkede ikiz kriz yaşandığını tespit etmekte ve sermaye akımlarındaki artışın aşırı kredi büyümesi ve aşırı değerli kura neden olduğu durumlarda bankacılık ve kur krizinin birlikte görüldüğünü söylemektedirler. Bankaların, döviz kurlarında yaşanan ani değişikliklerden dolayı riskleri bulunmaktadır. Kur krizi yaşanan dönemlerde taşıdıkları açık pozisyon döviz cinsi yükümlülüklerinde yükselişe neden olacaktır. Bankacılık krizi ise, bankaların likidite sıkıntısı nedeniyle ödemelerini yerine getirmemeleri sonucunda meydana gelmektedir. Parasal sıkışıklığın neden olduğu panik, mevduat sahiplerini de etkilemektedir. Bankalar yaşadıkları bu nakit sıkışıklığını, kredi kanallarının kuruması durumunda varlık satışı yoluyla çözmek zorunda kalabilirler. Bu durumda ise, varlıkların nakde çevrilme hızı ve piyasada oluşan anlık değeri önem kazanacaktır. 
Laeven ve Valencia (2018), 1970-2017 arasında dünyada gerçekleşen 151 sistemik bankacılık krizini araştırdıkları çalışmada, sistematik bankacılık krizlerini şirket ve finans sektöründeki iflaslar, finansal kurumların ve şirketlerin borçlarını zamanında ödeyememesi, takipteki kredilerin artması ve bankacı1ık sektörünün sermayesinin tükenmesi olarak açılamakta ve krizin gelişmiş ve gelişmekte olan ekonomilerde farklı etkileri olduğunu belirtmektedirler. Krizlerin, kişi başı milli geliri yüksek olan zengin ülkelerde orta ve düşük gelirli ülkelere göre daha uzun sürdüğünü, düşük mali bedel ödenmesine karşın daha yüksek çıktı açığına neden olarak genişletilmiş makro tedbirlere ve banka garantilerine daha fazla gerek duyulduğunu saptamıştırlar. Philippon ve Salord (2017), ise Avro bölgesindeki geri dönmeyen kredilerin 1 trilyon Avro'ya ulaştığını ve geri dönmeyen kredi rasyosunun \%10'u geçtiğini vurgulamakta ve zor durumdaki bankaların neden olduğu maliyetin üçte ikisini vergi veren vatandaşların ödediğini hesaplamaktadirlar.

Goodhard ve Avgouelas (2014), yaptıkları kurtarma operasyonlarının gerekliliğini savunan çalışmalarında, bankaları kurtarma kararını finansal istikrarın sağlanmasını hedefleyen vergi verenlerle kredi verenler arasında tercih yapmayı gerektiren, ülkenin ekonomik gücünü ve politik anlayışını da içeren bir durum olarak saptanmaktadır. Zararı kredi veren kurumlara yüklemek vergi verenleri korumacı bir yaklaşım olsa da finansal istikrarı olumsuz etkileyeceğini belirtmektedirler. Amerika'da finansal kurumların büyük sorumluluğunun olduğu finansal krizlerin tekrar yaşanmaması için çıkarılan, Dodd-Frank Yasası (Dodd-Frank Act), çok büyük olması nedeniyle batmasına göz yummama uygulamasını sona erdirmek amacıyla, tüketicilerin korunması ve finansal istikrarın korunması amaçlarını gözetmektedir. Avro bölgesinde ise, Banka Kurtarma ve Çözüm(leme) Yönergesi (Bank Recovery and Resolution Directive, BRRD) finansal kurumların, halkın parasıyla kurtarılmaması gerekli düzenlemelerin yapılması ve özel sektörün kurtarma paketlerindeki etkinliğinin artırılmasına yönelik çalışmaktadır.

Hamann vd. (2013), Kolombiya'da banka kredileri ve aktif büyüklüğü ile banka borçları ve kaldıraç arasındaki ilişkiyi belirtmiştir. Kaldıraç kullanımdaki artış çekirdek dışı yükümlülükler deki yükselişle mümkün olmaktadır. Bankaların çekirdek dışı borçlanmalarının, politikacılar için ekonominin yapısı ve gidişatı hakkında bir bilgi kaynağı olduğundan bahsederek, çekirdek dış1 yükümlülükler deki artışın finansal kırılganlığın öncü göstergesi olduğunu belirtmiştir. Harutyunyan vd. (2015), 2002-2013 dönemi için 26 ülkenin çekirdek ve çekirdek diş1 yükümlülüklerini inceleyerek, Türkiye'de çekirdek dışı yükümlülükler deki artışın, diğer ülkelerden daha yüksek olduğunu saptamıştır.

\section{Türkiye'de ÇDY}

2017 itibarıyla Türk bankacılık sektörünün çekirdek dışı yükümlülüklerinin \%60'ını, yurt dış1 piyasalardan tahvil ihraç ederek sağladığı fonlar ile bankalardan alınan krediler oluşturmaktadır. Yurt dışı yükümlülüklerin likidite gelişmelerinin yanında, kur, getiri farkları, yasal düzenlemeler, jeopolitik ve bölgesel gelişmeler gibi birçok değişkene duyarlı olması, borcun yenilenmesini ve teminini zorlaştırabilecektir.

Dünya Bankası 2017 istatistiklerini baz alarak gelişmekte olan ekonomilerin brüt dış borç stoklarını karşılaştırdığımızda, Türkiye'nin (437.9) milyar ABD tutarındaki borcu, Çin (1.607), Brezilya (545.7), Hindistan (483.4), Meksika (480.5) ve Rusya'dan (451) sonra 6. siradadır. Toplam özel sektör borcu ise, 200 milyar ABD doları ile (reel kesim + bankalar) Hindistan'dan sonra 4. sıradadır. Türkiye'nin toplam kısa süreli dış borcunun uluslararası rezervlere oranı 2008 yılında \% 71 iken, 2017'de \%109,35'e yükselmiş ve dünya ortalamas $\%$ 76,43 olarak saptanmıştır.

Kısa süreli dış borcun toplam dış borca oranı da \%25,89 ve dünya ortalamas1 \%12,1'dir. 2020 yılında verilerine göre bankaların yurt dışından kullandıkları kısa vadeli krediler de \%10,2 oranında artış görülmektedir. Toplam dış borcun GSYİH'ya oranı \%53,5 ve dünya ortalaması $\% 51,49$ 'dur. Türkiye'nin birlikte değerlendirildiği gelişmekte olan ülkeleri dikkate aldığımızda 
oranlar, Güney Afrika \%52, Meksika \%40,5, Rusya \%32, Hindistan \%19,76, Brezilya \%26,9 ve Çin'de \%14,01 değerinde bulunmaktadır.

Şekil 1. Çekirdek Dışı Yükümlülüklerin Toplam Yükümlülüklere Oranı



Kaynak: TCMB Finansal İstikrar Raporu 2019

Çekirdek dışı yükümlülüklerin, çekirdek yükümlülüklere oranı 2008'den sonra hızlı bir artış göstermektedir. (Bkz. Şekil 1). Gelişmekte olan ekonomilerin son 10 yılda kredi kullanımlarını genişlettikleri izlenmekle birlikte, Türkiye'nin kredi genişlemesi diğer ekonomilerden daha yüksektir. Bu kredi büyümesinin, çekirdek dışı yurt dışı fonlarla finanse edildiğini, mevduattaki genişlemenin, kredilerdeki genişlemeden az olması ile açıklayabiliriz. Türk bankacılık sektörünün finansman aracı olarak yurt dışı borçlanmaya yönelmesi ise, ani sermaye çıkışlarının olduğu dönemlerde likidite riskinin şiddetini ve bu likidite sıkıntısının sebep olabileceği sistemik riskin, yıkıcılığını artırmaktadır. Şekil 2'de BİST'e kote 278 reel sektör firmasının piyasa ve bilanço verileri kullanılarak hesaplanan ağırlıklı temerrüt olasılığı ile ülkemiz kredi temerrüt takası (credit default swap, $C D S$ ) spreadleri karşılaştırılmaktadır. İki veri arasında yüksek oranda korelasyon olması, hesaplanan risk primleri ile firma temerrüt riski arasındaki ilişkinin kuvvetli olduğunu göstermektedir. Bu nedenle bankaların aktif kalitesi ve kredi riski analizinde reel sektör temerrüt olasılığı yakından takip edilmelidir. 
Şekil 2. Reel Sektör Temerrüt Olasılı̆̆ı (PD) ve Kredi Temerrüt Takası (CDS)

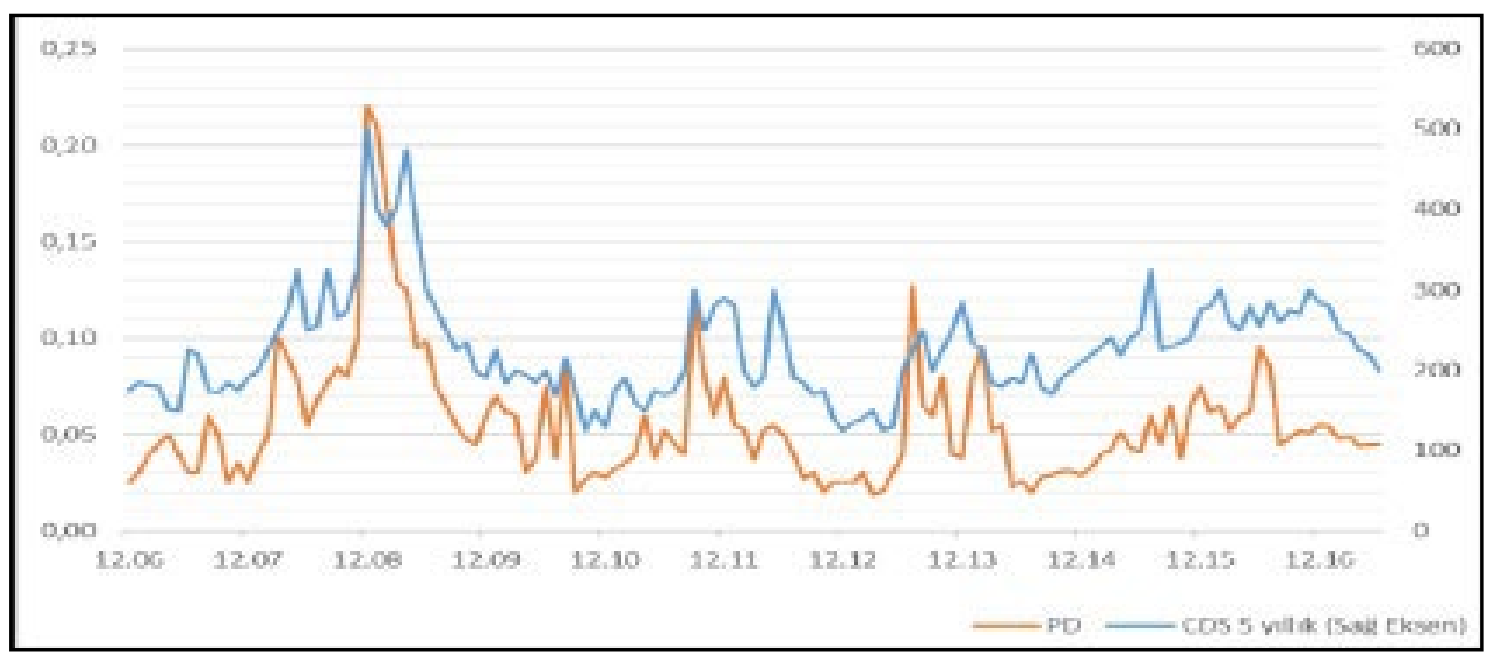

Kaynak: TCMB, Finansal Piyasalar, (12- 2017)

Tablo 1'de yükselen ekonomilerde finans dış1 özel sektörün kullandı̆̆ 1 toplam kredilerin GSYİH'ya oranının uzun vadeli eğilim ile arasındaki farkı, Tablo 2'de ise, borç servis oranlarının yani, dış borç anapara faiz ve diğer ödemelerin yıllık toplamının cari ödemeler bilançosunda yer alan döviz kazançlarına (ülkenin ihracatına) oranı görülmektedir.

Tablo 1. Gelişmekte Olan Ülkeler ve Türkiye'de Finans Dışı Özel Sektörün Kredi-GSYİH Açı̆̆g (2013-2018)

\begin{tabular}{lllllll}
\hline & $\mathbf{2 0 1 3}$ & $\mathbf{2 0 1 4}$ & $\mathbf{2 0 1 5}$ & $\mathbf{2 0 1 6}$ & $\mathbf{2 0 1 7}$ & $\mathbf{2 0 1 8 / 3 . C ̧}$ \\
\hline Brezilya & 7.8 & 7.6 & 9.5 & 0.8 & -3.1 & -3.9 \\
Çin & 18.4 & 21.0 & 20.2 & 17.7 & 9,6 & 3.0 \\
Hindistan & -0.1 & -3.3 & -3.8 & -8.1 & -8.6 & -7.0 \\
Kore & 1.4 & 2.2 & 1.7 & -0.2 & -2.4 & 0.5 \\
Meksika & 6.3 & 6.3 & 7.7 & 8.5 & 6.3 & 3.9 \\
Rusya & -0.1 & 8.6 & 7.1 & -2.6 & -6.9 & -7.5 \\
G. Afrika & -3.3 & -3.9 & -0.7 & -3.1 & -3.5 & -2.3 \\
Türkiye & 13.3 & 10.8 & 9.8 & 9.9 & 5.1 & 11.3 \\
\hline
\end{tabular}

Kaynak: BIS Statistics, kredi/GSYİH Rasyoları, 27/Şubat/2019

*Kredi/GSYIH açığı, kredi/GSYIH oranının uzun vadeli trend olan farkıdır. Uzun vadeli trend hesaplaması, tek taraflı Hodrick Prescott filtresi Lambda 400.000 kullanılarak hesaplanmıştır.

Tablo 1'de Çin devleti genel trendden ayrılmasına karşın 2017 itibarıyla küçülme göstermekte, Türkiye ise, trendle pozitif bir eğilim içinde olmasına karşın (TCMB tarafından kabul edilen eşik değerler \%3-\%15), 2018 yılında diğer ülkelerden ayrışarak yüksek oranda $(\% 11,3)$ kredi-GSYİH açı̆̆ı göstermektedir. 
Tablo 2'de, Türkiye'nin y1llar itibariyle borç servis oranının yükseldiği, 2018' de ise \%80 oranında çok yüksek artış kaydettiği gözlenmektedir.

Tablo 2. Gelişmekte Olan Ülkelerde ve Türkiye'de Borç Servis Oranı

\begin{tabular}{lllllll}
\hline & $\mathbf{2 0 1 3}$ & $\mathbf{2 0 1 4}$ & $\mathbf{2 0 1 5}$ & $\mathbf{2 0 1 6}$ & $\mathbf{2 0 1 7}$ & $\mathbf{2 0 1 8 / 3 . C ̧}$ \\
\hline Brezilya & 14.8 & 16.7 & 20.7 & 23.2 & 19.8 & 16.6 \\
Çin & 18.4 & 19.5 & 19.2 & 19.4 & 19.6 & 19.3 \\
Hindistan & 8.9 & 8.8 & 8,4 & 8.0 & 7.8 & 7.3 \\
Kore & 20.6 & 20.1 & 20.0 & 19.6 & 19.8 & 20.5 \\
Meksika & 3.6 & 3.7 & 3.9 & 4.3 & 4.7 & 5.1 \\
Rusya & 7.4 & 9.1 & 12.2 & 10.5 & 8.8 & 7.9 \\
G. Afrika & 7.7 & 7.7 & 8.1 & 8.5 & 8.7 & 8.9 \\
Türkiye & 9.7 & 11.8 & 13.3 & 14.3 & 15.4 & 27.7 \\
\hline
\end{tabular}

Kaynak: BIS Ulusal Veriler

Sorun, üretim artışı sağlayan kredi genişlemesi ile aşırı kredi büyümesinin farkının ölçümlenebilmesidir. Saltoğlu (2012), bu durumu, "Büyümelerimizin küresel şartlar iyiyken çok hızlandı̆̆ını, kötüleştiğinde ise sert düşüş gösterdiğini ortaya koymaktadır." şeklinde yorumlamaktadır.

Tablo 3. Gelişmekte Olan Ülkeler ve Türkiye'de Büyümenin Volatilitesi (2014-2018)

\begin{tabular}{lll}
\hline & Ortalama GSYï (2014-18 ) & Büyümenin Standart Sapması \\
\hline Türkiye & 4.90 & 2.00 \\
Hindistan & 7.58 & 0.50 \\
Çin & 6.86 & 0.30 \\
Brezilya & -0.82 & 2.36 \\
G. Afrika & 1.12 & 0.54 \\
G. Kore & 2.96 & 0.24 \\
Rusya & 0.48 & 1.84 \\
\hline
\end{tabular}

Kaynak: BIS Ulusal Veriler, (03/2019)

Türkiye Brezilya'dan sonra en yüksek oynaklık seviyesindedir. Brezilya ise, son yıllarda büyüme gerçekleştirememiştir ve Fitch'in 2018 yılı değerlendirmesinde ülke notu BB den BB-'ye düşürülmüştür. Fitch not indirim kararına etken olan ekonomik durumu "Brezilya'nın yüksek kamu borcu, artan bütçe açıkları, yerine getirilmeyen reform sözleri" üzerine yaptıkları tespitleri göstermektedir. Büyümenin, Rusya'da küresel ekonomideki yavaşlama sebebiyle düşen petrol fiyatlarından, Güney Afrika'da ise, gerileyen altın talebi sonucu yaşanan ekonomik daralmadan negatif etkilediğini söyleyebiliriz.Türkiye'nin 2014-2018 periyodunda ortalama \%4,9 oranında gerçekleştirdiği büyüme, diğer ülkelerden çok yüksek oynaklık seviyesi göstermektedir. 
Türkiye'de firmalar, ihracat gelirleri karşısında kredi kullanmak istediklerinde döviz kredilerinin çok daha ucuz maliyetli ve daha uzun vadeler içermesi nedeniyle döviz bazlı kredilere yönelmektedirler. Bankalar ise; FX kredi kanallarını (döviz mevduat, sendikasyon, bond vb.) kanallarını kullanarak, kur riskini müşterilerine transfer etmektedir. Yılmaz (2020), bankaların FX ÇDY'in, FX ÇY'in 3 katına ulaştığını tespit ederek, döviz mevduatların vadesinin sendikasyon kredilerinden kısa olmasının tercihlerde etken rol oynadığını ve bu kanalların küresel ve lokal makro ekonomik politikalardan etkilendiğini söylemektedir.

Tablo 4'te, sektörün bilanço içi yabancı para pozisyonunda açığın büyümekte olduğu görülmektedir. Bilanço içi verilen açık pozisyon swap işlemleri kanalıyla, net pozisyonda kapanmakta ve sağlanan finansman TL kredi talebine kaynak imkânı sağlayabilmektedir. Swap işlemleri sonucu açık pozisyon olmamasına karşın, bankacılık sektörünün çekirdek dışı yurt dışı yükümlülüklere ağırlık vermesi nedeniyle, bilançoların pasif kısmı dolarize olmaktadır.

Tablo 4. Türk Bankalarının Yabancı Para Pozisyonu (2012-2019)

\begin{tabular}{lllllllll}
\hline & $\mathbf{2 0 1 2}$ & $\mathbf{2 0 1 3}$ & $\mathbf{2 0 1 4}$ & $\mathbf{2 0 1 5}$ & $\mathbf{2 0 1 6}$ & $\mathbf{2 0 1 7}$ & $\mathbf{2 0 1 8}$ & $\mathbf{2 0 1 9}$ 1.Ç \\
\hline Dışı & 31 & 63 & 71 & 96 & 71 & 184 & 191 & 274 \\
İçi & -28 & -64 & -77 & -93 & -75 & -182 & -176 & -278 \\
\hline
\end{tabular}

Kaynak: BDDK, Bankacılık Temel Göstergeleri 05/2019)

Türk bankacılık sektörünün ÇDY üzerine az sayıda çalışma bulunmaktadır. Binici (2012), ÇDY'in Türk bankacılık sisteminde önemli bir kaldıraç enstrümanı olarak kullanıldığı belirtmektedir. Kılınç vd. (2013), Türkiye'de ÇDY ve kredi genişlemesi arasında kuvvetli bir ilişki bulunduğunu tespit etmiştir. Yılmaz (2016), bankacılık sektörünün borçlanmada dolarize olduğunu belirtmekte ve döviz cinsi yükümlülüklerdeki artışın, ÇDY’le finanse edildiğini tespit etmektedir.

Ekonomik dalgalanmalardan en olumsuz şekilde etkilenen, benzer ekonomik gelişmeleri gösteren ve büyük miktarda dış finansman ihtiyacı olan, Türkiye'nin de birlikte değerlendirildiği kırılgan beşli ülkeleri karşılaştırıldığında en yüksek Dış Borç/GSYIHH oranı Türkiye'de görülmektedir. Ancak 2017 yılında, Türkiye kırılgan beşli olarak tanımlanan ülkeler grubunda yer almaya devam ederken, birlikte değerlendirildiği diğer ülkelerin iyileşme kaydederek gruptan çıktığını ve gruba yeni ülkelerin dâhil olduğunu görmekteyiz. Türkiye'nin dış borcu artmakta ve Türkiye Standard\&Poor tarafından dövize en çok ihtiyacı olan ülkeler içinde tanımlanmaktadır.

Tablo 5. Kırılgan Beşli 2018 Yılı Dış Borç Stoku/GSYIH Miktarları

\begin{tabular}{lll}
\hline & Milyar USD & Dış Borç / GSYİH (\%) \\
\hline Türkiye & 444.80 & 56.7 \\
Güney Afrika & 291.90 & 46.9 \\
Endonezya & 376.80 & 36.2 \\
Brezilya & 559.21 & 30.0 \\
Hindistan & 510.40 & 20.8 \\
\hline
\end{tabular}

Kaynak: CIEC 
Şekil 3'de, kırılgan beşli olarak değerlendirilen, Hindistan, Endonezya, Brezilya, Güney Afrika ve Türkiye'nin çekirdek dışı borçlanmalarının GSYİH'ya olan oranlarının 2010 ve 2018 yılları arasındaki gelişimini göstermektedir. Türkiye dışındaki ülkelerde 2015-2016 yıllarında görülen artış eğiliminin ise, 2016'dan itibaren tekrar azalışa döndüğü gözlenmektedir. Türkiye, genel trendden farklı bir çizgi sergilemekte ve eğilimin 2010'dan itibaren artış göstererek 2016'da başlayan genel azalış trendine karşın, yükselişini sürdürdüğü görülmektedir.

Şekil 3. Kırılgan Beşli ÇDY/GSYIHH Oranları Karşılaştırması

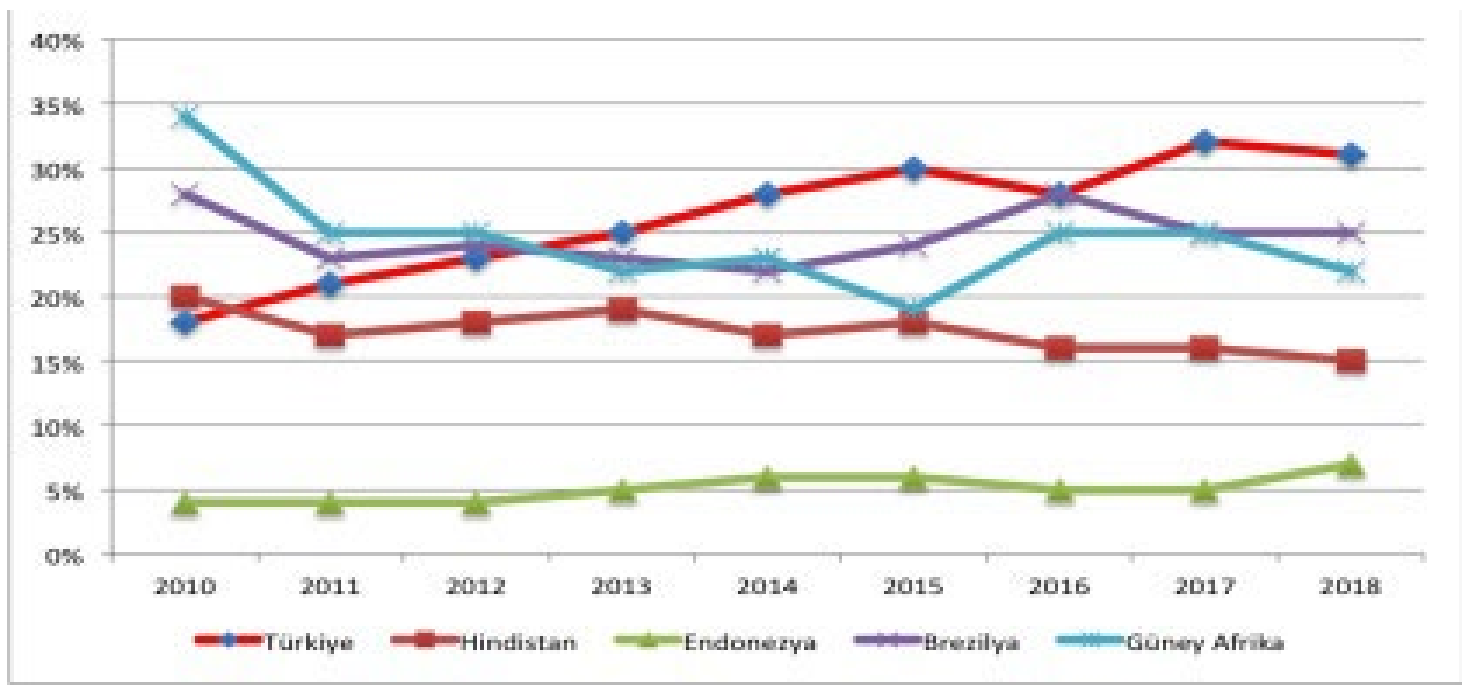

Kaynak: The Global Economy, http://www.theglobaleconomy.com

\section{Ekonometrik Analiz}

\subsection{Modellerin Yapısı ve Analiz Yöntemi}

Bankacılık sistemine dair verilerin zaman ve kesit olarak iki boyutlu yapı içermesi nedeniyle, analiz tekniği seçiminde panel veri modellemeleri tercih edilmektedir.). "Panel veri (longitudinal veya cross sectional time series) parametrelerin zamana karşı değişimlerini gözlemleyerek gerek birimler gerekse birimlerin içerisinde zamana göre meydana gelen farkl1lıkların birlikte incelenmesine olanak vermektedir." (Tunay ve Tunay, 2011).

"Panel veri modelleri diğer yöntemlere nazaran daha karmaşık davranış modellerinin kurulmasına ve test edilmesine olanak verir. Çeşitli nedenlerle dişlanan değişkenler, zama serisi veya kesit verisine dayalı model tahminlerinde, sonuçlarda sapmaya yol açmaktadır. Oysa model dışında tutulan değişken ve değişkenlerin birimlere veya zamana göre değişmeyen değişkenler olması durumunda, panel veri kullanımı sapmanın kontrol altına alınmasını sağlamaktadır."

$\mathrm{Bu}$ modellerden "sabit etkiler" (fixed effect) modeli, parametrelerin zaman içinde değişiklik göstermeyen özelliklerinin (error terms) kendilerine has olduğunu kabul ederek hesaplamadan çıkarır ve net etkiyi hesaplar. Böylece, değişkenlerle gözlemlenen değişken arasındaki net etkiyi görebilmemizi sağlar. Greene (2003), eğer zaman içinde değişmeyen özellikler arasında korelasyon varsa, "sabit etkiler" modeli yerine "rassal etkiler" (random effect) modelinin tercih edilmesi gerekmektedir. Reyna (2007), rassal etkiler modeli ise, genellikle tesadüfi şekilde sabit bir terim içermektedir. Bu modelde hesaba katılmayan açıklayıcı değişkenlerin veya hatanın elde edilmesi amacıyla, model sabitinin hesaplamalar sonucunda rassal olarak belirleneceği varsayılır. Modelde ele alınan parametrelerin hata terimlerinin (gruba özel hata terimi), gözlemlenen değişken hata terimi ile korelasyonu yoktur ve bu nedenle zamana göre değişmeyen değerler sonuçları etkilemektedir. 
Bu durumun sınanması için, başlangıçta aynı değişkenler hem sabit etkiler hem de rassal etkiler modelleriyle tahmin edilerek, elde edilen kalıntı dizilerine "Hausman" testi uygulanmaktadır. Hausman testi, tekil hata terimlerinin açıklayıcı değişkenlerle ilişkili olup olmadıklarını test eder. $\mathrm{Bu}$ test için yokluk hipotezi (veya $H_{0}$ hipotezi), hata terimleri ile açıklayıcı değişkenlerin ilişkili olmadıkları veya teknik olarak katsayılar arasında sistematik fark olmadığ 1 şeklindedir. Yokluk hipotezi kabul edilirse analizler rassal etkiler, reddedilirse de sabit etkiler modeli kullanılarak yapılmalıdır. Sabit etkiler modelinin aksine rassal etkiler modelinde, bağımsız veya açıklayıcı değişkenlerin farklı kesitlerde rassal ve ilişkisiz oldukları varsayılmaktadır. Eğer katsayılar arasında önemli farklılıklar tespit edilirse (korelasyon), sabit etkiler modeli önerilmektedir. Hausman testi sonucunun sabit etkiler modelini işaret etmesi nedeniyle, araştırma bu yönde ilerlemiştir.

Tek değişkenli basit bir "sabit etkiler” modeli eşitliği aşağıdaki gibi tanımlanabilir:

$\mathrm{Y}_{\mathrm{it}}=\beta_{1} \mathrm{X}_{\mathrm{it}}+\alpha_{\mathrm{i}}+\mathrm{u}_{\mathrm{it}}$

(1) numaralı eşitlikte; $\alpha_{\mathrm{i}}(\mathrm{i}=1, \ldots, \mathrm{n})$ kesit bazındaki model sabitini, $Y_{\text {it }}$ bağımlı değişkeni, $\mathrm{X}_{\mathrm{it}}$ bağımsız değişkeni, $\beta_{1}$ ilgi parametresini, $u_{i t}$ hata terimini simgeler. Bu eşitlikte, $i$ ve $t$ alt indisleri sırasıyla kesit veya grup sayısı ile kesit başına zamanı tanımlamaktadır.

Sabit etkiler modeli ile elde edilen bulgulara, kesitsel bağımsızlığın sınanması için Breusch-Pagan LM (B-P/LM) bağımsızlık testi ve ardından ardışık bağlanımın (autocorrelation) tespiti için Lagranj çarpanı (Lagrange multiplier/LM) testi uygulanmaktadır. Panel veri analizlerinde yatay kesit bağımlılığının dikkate alınması gerektiğini Robertson ve Simons (2000), Pesaran (2004), Breusch ve Pagan (1980), çalışmaları ile ortaya koymuştur. Philips ve Sul (2003), yatay kesit bağımlılığının dikkate alınmadığı durumlarda etkin olmayan sonuçlar alındığını tespit etmektedirler. Kesit bağlılı̆g bulunması tahmin sürecinde sorunlara neden olmakta ve hata terimleri birbirlerini etkileyerek yanlış sonuçlara yol açabilmektedir. Araştırmalarda yatay kesit bağımsızlığı tespitinde, zaman boyutu, birim boyutundan büyük olduğu durumlarda Breusch Pagan, Pesaran, Ullah ve Yamagata veya Lagrange çarpanı $(L M)$ testleri tercih edilmektedir.

"Breusch Pagan testi bir LM testidir." (Keskin ve Aksoy, 2019). Breusch Pagan testi, n sabitken ve $\mathrm{t}$ sonsuza giderken $(\mathrm{t} \rightarrow \infty)$, kalıntıların korelasyon katsayılarını temel alan bir LM testidir. Testin yokluk veya $\mathrm{H}_{0}$ (null hypothesis) hipotezi kalıntıların birimler arasında korelasyonu olmadığı "yatay kesit bağımlılığı yoktur" şeklindedir.

Tahmin sürecinde kalıntıların değişen varyans (heteroscedasticity) sorunu olup olmadığı Wald testi ile test edilmektedir. Wald testinde (Wald Chi-Squared Test) modelde yer alan değişkenlerin modele olan katkıları saptanmaktadır. Eğer değişkenin bir etkisi yoksa model dışında bırakılması daha doğrudur. Testin yokluk veya $\mathrm{H}_{0}$ hipotezi, "varyansın birimlere göre değişmediği ve sabit varyanslı (homoscedastic) olduğu" şeklindedir.

\subsection{Veri Seti}

Çalışmamızın temelini oluşturan veri seti, IMF'nin ülke bazında bankacılık sektörüne yoğunlaşmış olan Uluslararası Finansal İstatistikler (IFS)'in Financial Soundness Indicators (FSI) veri tabanından derlenmiştir. Kırılgan beşli olarak nitelenen ülkelerin ÇDY gelişimi, bankacılık ve kur krizlerine olan etkileri analiz edileceğinden, ülke bazında açıklanmış konsolide bankacılık verileri derlenmiştir. Bu çerçevede kırılgan beşli olarak adlandırılan Türkiye, Hindistan, Brezilya, Endonezya ve Güney Afrika'nın 2010-2019 birinci çeyrek dönemi baz alınarak 10 yıllık bir veri seti oluşturulmuştur. FSI veri setinden derlenen ÇY, müşteriler mevduatı, interbank mevduatı, diğer para ve mevduatlar toplamından oluşmaktadır. ÇDY tutarları ise, bilanço toplamından, ÇY ile sermaye ve rezervler düşülerek hesaplanmıştır. Krediler toplamı, yabancı para cinsi borçlar toplamı vb. bilgiler, yine FSI veri setinden temin edilmiştir. 
ÇDY'in krizlerle olan etkileşimini araştırmak amacıyla bankacılık ve kur krizleri seçilmiştir. Borsa krizi ise, Hahm v.d. (2012), yaptığı çalışmada korelasyon görülmemesi ve bu ülkelerde sermaye piyasalarının derin olmamasının neden olabileceği yanıltıcı sonuçlar nedeniyle göz ardı edilmiştir. Kur krizi tahmini hesaplamasında Hahm'ın, Frankel ve Rose'u takip ederek seçtikleri yöntem kullanılmıştır. Bu yöntem, kurdaki değer kaybının \%10 ve takip eden yılda $\% 25$ olmasını kur krizi olarak tanımlamaktadır. Bankacılık krizi için, 2011 Avrupa Bankacılık Krizi (European Banking Crises) tanımlanmıştır. Kur ve bankacılık krizleri kukla değişkendir (dummy variable) ve ayrı çalışmalarda sorgulanmaktadır. Bağımsız değişkenler, bilançoların pasif kısmı dikkate alınarak, borçlanma artışını ve borçlanma artışının kârlılığa olan etkisini araştırabileceğimiz verilerden seçilmiştir.

Tablo 6. Modellerde Verilen Değişkenler ve Birimleri (Ulusal para birimi milyon)*

\begin{tabular}{lll}
\hline ÇDY & NCL & Çekirdek Dışı Yükümlülükler \\
\hline ÇY & Customer Deposit & Çekirdek Yükümlülükler \\
Krediler & Total Loan & Toplam Verilen Krediler \\
Sermaye ve Rezervler & Capital Reserve & Sermaye ve Rezervler \\
ÇDY/ÇY & NCL/Customer & Çekirdek Dışı Yükümlülük/Çekirdek \\
& Deposit & Yüküm. \\
Aktif Toplamı & Balance sheet & Aktif Toplamı \\
NPL & NPL & Tahsil Edilemeyen Krediler \\
Yabancı Para Cinsi & Forgcurency & Yabancı Para Cinsi Borçlar/Toplam \\
Borçlar/Toplam Borç & Liabilities/T.Liabilities & Borçlar \\
Likit Varlıklar/KSB & Liquasset/Short Time & Likit Varlıklar/Kısa Süreli Borçlar \\
& Liabilities & \\
Kaldıraç & LVG & Kaldıraç Oranı \\
\hline & & \\
\hline ROE & ROE & Sermaye Kârlılı̆̆1 \\
ROA & ROA & Aktif Kârlılığı \\
K/M & Loan /Deposit & Krediler Toplamı/Mevduat Toplamı \\
Toplam Borçlar & Total Liabilities & Borçlar Toplamı \\
Kukla Değişken ${ }^{1}$ & Currency Crisis & Kur Krizi ** \\
Kukla Değişken ${ }^{2}$ & Banking Crisis & Bankacılık Krizi *** \\
\hline
\end{tabular}

*Ulusal para birimleri milyon bazındadır ve Amerikan Dolar karşılığı değerleri kullanılmıştır.

(1) 2010-2019 arasında kur krizi gerçekleşen dönem "1", diğer dönemler "0" olarak tanımlanmıştır.

(2) 2010-2019 arasında banka krizi gerçekleşen dönem "1", diğer dönemler "0" olarak tanımlanmıştır.

\subsection{Tahmin ve Bulgular}

Farklı frekans yapısındaki kur krizi ve bankacılık krizi ayrı ayrı araştırılmaktadır. Her iki örneklem için sabit etki $(f e)$ ve rassal etki ( $r e$ ) panel veri modelleri tahmin edilmiş ve kullanılan değişkenlerin karşılıklı etkileşimlerini yansıtan korelasyon katsayıları analizin bir ön adımı olarak 
hesaplanmıştır. Tahmin sürecinde kullanılan sabit etkiler modelinin yapısı (1) numaralı eşitlikten hareketle aşağıdaki gibi gösterilebilir:

$\mathrm{CCDY}_{\mathrm{it}}=\beta^{\prime} \mathrm{X}_{\mathrm{it}}+\alpha_{\mathrm{i}}+\mathrm{u}_{\mathrm{it}}$

(2) numaralı eşitlikte $X_{\text {it }}$ bağımsız değişkenler vektörüdür ve ÇDY dışındaki değişkenlerden meydana gelmektedir. $\beta$ ise bu değişkenlerin parametreler vektörüdür: $\beta=\left(\beta_{1}, \beta_{2}, \ldots, \beta_{\mathrm{k}}\right)$. $\alpha_{\mathrm{i}}$ ve $\mathrm{u}_{\mathrm{it}}(1)$ numaralı eşitlikte tanımlandıkları gibi gruba özel sabitleri ve hata terimlerini simgelemektedir. (2) numaralı eşitlik tüm değişkenleri içeren referans modeldir. İzlenen yaklaşım; önce tüm değişkenleri içeren referans modelin tahmini, ardından anlamsız değişkenlerin tek tek elenerek sadece anlamlı değişkenleri içeren model yapısının kurulmasıdır.

Tablo 7. Kur Krizinin Etkisini Yansitan Referans Modelin Sabit Etkiler Tahmini

\begin{tabular}{lllll}
\hline Bağımlı değişken: ÇDY & & & & \\
Bağımsız Değişkenler: & Katsayı & Std. Hata & t Testi & p Değeri \\
\hline Kur Krizi & -.0311021 & .0427238 & -0.73 & 0.471 \\
Aktif Toplamı & .6375884 & .112286 & 5.68 & 0.000 \\
ÇDY/ÇY & 3.849158 & .6363924 & 6.05 & 0.000 \\
ÇDY/Bilanço Toplamı & -7.31216 & 1.475966 & -4.95 & 0.000 \\
Kaldıraç & -9.167171 & 1.261424 & -7.27 & 0.000 \\
Likit Var./KSB & -.0025466 & .0011585 & -2.20 & 0.034 \\
Y.P.Borç./Top. Borç. & .0190772 & .003924 & 4.86 & 0.000 \\
Sabit (cons) & 11.51591 & 2.333476 & 4.94 & 0.000 \\
R Kareler: & & & & \\
İçinde & 0.8895 & & Sigma u & 1.04179 \\
Arasında & 0.0047 & & Sigma e & 0.08112 \\
Genel & 0.0270 & & Ro & 0.99397 \\
F Testleri: & & & & \\
Modelin F Testi (6, 39) & 43.69 & 0.0000 & & \\
Kalıntıların F Testi (4, 38) & 18.78 & 0.0000 & & \\
\hline
\end{tabular}

Tablo 8. Banka Krizinin Etkisini Yansitan Referans Modelin Sabit Etkiler Tahmini

\begin{tabular}{lllll}
\hline Bağımlı Değişken: ÇDY & & & & \\
Bağımsız Değişkenler: & Katsayı & Std. Hata & t Testi & p Değeri \\
\hline Aktif Toplamı & .157612 & .5415191 & 0.29 & 0.773 \\
Likit Var./KSB & -.0013027 & .0012016 & -1.08 & 0.286 \\
Aktif Kârlılığı & .0121269 & .0524104 & 0.23 & 0.818 \\
Bankacılık Krizi & -.0811448 & .0546797 & -1.48 & 0.148 \\
ÇY & -3.114498 & 1.453721 & -2.14 & 0.040
\end{tabular}




\begin{tabular}{lllll} 
Kaldıraç & -8.613297 & 1.955479 & -4.40 & 0.000 \\
Toplam Krediler & 3.578329 & 1.340473 & 2.67 & 0.012 \\
Kredi/Mevduat & -2.792085 & 1.051979 & -2.65 & 0.012 \\
ÇDY/ÇY & 5.677819 & 1.207086 & 4.70 & 0.000 \\
ÇDY/Bilanço Toplamı & & -11.36038 & -4.92 & 0.000 \\
Sermaye Rezerv & & 2.310713 & & \\
& & -.1645042 & -1.47 & 0.152 \\
Y.P.Borç./Top. Borç. & .0196257 & .1121661 & & \\
Geri Dönmeyen Krediler & .015115 & .0083408 & 2.35 & 0.025 \\
Sabit (cons) & 16.79657 & 4.085646 & 4.11 & 0.000 \\
R Kareler: & & & & \\
İçinde & 0.9264 & & Sigma u & 1.0191753 \\
Arasında & 0.1405 & Sigma e & 07213157 \\
Genel & 0.1695 & & Ro & 99501594 \\
F Testleri: & & & & \\
Modelin F Testi $(13,32)$ & 31,00 & 0.0000 & & \\
Kalıntıların F Testi (4, 32) & 11.97 & 0.0000 & & \\
\hline
\end{tabular}

Devam edilecek modele karar verebilme amaciyla "Hausman" testi uygulanarak sabit etkiler modeli ile tahmin yapılmasının gerektiği saptanmıştır. (Bkz. Tablo 9

Tablo 9. Hausman Testlerinin Sonuçları

\begin{tabular}{lll}
\hline & Model $1^{*}$ & Model 2** \\
\hline Ki Kare & 48.12 & 29.31 \\
p Değeri & 0.0000 & 0.0000
\end{tabular}

$(*)$ Kur krizlerinin etkilerini yansitan model

(**) Banka krizlerinin etkilerini yansitan model

Bir sonraki adımda, referans model için sabit etkiler modeli her iki örneklem için tekrar uygulanarak, anlamlı katsayılar içeren modeller kurulmaya çalışılmıştır. Bu aşama, istatistiki olarak anlamlı olmayan değişkenlerin tek tek modelden çıkartılmasını ve analizin tekrarlanmasını gerektiren bir süreci kapsamaktadır. Tahmini yapılan tüm modellere "tanı koyma" (diagnostic) testi olarak Breusch ve Pagan Lagrange Çarpanı testi uygulanmıştır.

Kalıntıların Korelasyon Matrisi, 
Tablo 10. Breusch ve Pagan Testi Kur Krizi

\begin{tabular}{llllll}
\hline & e1 & e2 & e3 & e4 & e5 \\
\hline e1 & 1.0000 & & & & \\
e3 & 0.3816 & 1.0000 & & & \\
e4 & -0.0655 & -0.0948 & 1.0000 & & \\
e5 & 0.5339 & 0.1844 & -0.1833 & 1.0000 & \\
Ki Kare & 0.6285 & 0.5102 & -0.2490 & 0.2136 & 1.0000 \\
\hline
\end{tabular}

Tablo 11. Breusch ve Pagan Testi Bankacılık Krizi

\begin{tabular}{llllll}
\hline & e1 & e2 & e3 & e4 & e5 \\
\hline e1 & 1.0000 & & & & \\
e2 & -0.0202 & 1.0000 & & & \\
e4 & -0.0457 & 0.1636 & 1.0000 & & \\
e5 & 0.6491 & -0.1886 & -0.0798 & 1.0000 & \\
Ki Kare & 0.2095 & 0.6136 & -0.1657 & 0.0013 & 1.0000 \\
\hline
\end{tabular}

Test sonucu elde edilen Pr değerleri yatay kesit bağımlılığı olmadığını göstermektedir. Bir sonraki adımda ise, kesitler bazında değişen varyans (heteroscedasticity) sorunu bulunup bulunmadığını belirlemek için Wald testleri uygulanmıştır ve sonuçları Tablo 12'de sunulmuştur.

Tablo 12. Wald Testlerinin Sonuçları

\begin{tabular}{lll}
\hline & Bağımlı Değişken & \\
& Kur Krizi & Banka Krizi \\
\hline Ki Kare & 28.00 & 465.36 \\
p Değeri & 0.000 & 0.000 \\
\hline
\end{tabular}

Wald testinin yokluk $\mathrm{H}_{0}$ hipotezi varyansın sabit olduğu (homoscedasticity), alternatif $\mathrm{H}_{1}$ hipotez ise değişen varyans olduğu yönündedir. Bu aşamada Wald testinin sonuçları, kesitler arasında değişen varyans sorunu olduğunu işaret ettiği için, değişen varyansa karşı sağlam standart hatalar hesaplanmıştır. Bu şekilde hem genel anlamlılığı hem de açıklama gücü yükssek tahminlere ulaşılmıştır. (Bkz. Tablo 13, 14) 
Tablo 13. Săglam Standart Hatalarla Kur Krizinin Etkisini Yansitan Rafine Modelin Tahmini

\begin{tabular}{lllll}
\hline Robust & \multicolumn{5}{l}{ (Std. Err. adjusted for 5 clusters in grup) } \\
Bağımlı Değişken: ÇDY & & & & \\
\hline Bağımsız Değişkenler: & Katsayı & Std. Hata & t Testi & p Değeri \\
Aktif Toplamı & 0.669584 & 0.1687078 & 3.97 & 0.017 \\
ÇDY/ÇY & 3.784086 & 1.024138 & 3.69 & 0.021 \\
ÇDY/Bilanço Toplamı & -7.149294 & 3.058108 & -2.34 & 0.080 \\
Kaldıraç & -9.048924 & 2.198656 & -4.12 & 0.015 \\
Likit Varlıklar/KSB & -0.002261 & 0.000936 & -2.41 & 0.073 \\
Y. P. Borç/Top. Borç & 0.017846 & 0.005406 & 3.30 & 0.030 \\
cons & 10.96218 & 4.427237 & 2.48 & 0.068 \\
R Kareler: & & & & \\
İçinde & 0.8879 & & Sigma u & 0.99315556 \\
Arasında & 0.0322 & & Sigma e & 0.08063595 \\
Genel & 0.0681 & & Ro & 0.99345109 \\
\hline
\end{tabular}

Regresyon bağımsız değişkendeki bir birimlik artışın, bağımlı değişkende meydana getirdiği etkiyi göstermektedir. Bağımsız değişkenler zaman ve ülkeler bazında gerçekleşen bir birimlik değişimin, bağımlı değiş̧ken üzerindeki etkisini ölçmektedir.

Elde edilen sonuçlara göre, aktif toplamı, çekirdek dışı yükümlülüklerin, çekirdek yükümlülüklere oranı $(C \zeta D Y / C \zeta Y)$ ve yabancı para ile yapılan borçlanmanın toplam borca olan oranı (Y.P Borç/Top. Borç) çekirdek dışı yükümlülüklerle (ÇDY) pozitif etkileşim içerisindedir.

Bu etkileşim, bankacılık sektörünün, finansal döngünün genişleme fazında kredi verme iştahını artırdığı ve mevduatın kredi ihtiyacını karşılamada yetersiz kaldığı dönemlerde oluşan finansal açığı, ÇDY'e yönelerek tamamladığını göstermektedir. Aktif toplamında bir birimlik artış, ÇDY'de 0,66 birimlik artışa, ÇDY/ÇY oranındaki bir birimlik artış ÇDY'de 3,78 birimlik artışa neden olmaktadır. ÇDY yurt dişı borçlanma etkin rol oynamakta ve her bir birimlik döviz cinsinden borçlanma 0,018 oranında ÇDY'le sağlanmaktadır. Bu bağlamda, bankaların kısa vadeli likidite pozisyonlarının maliyeti önem kazanacaktır. Kısa vadeli likidite pozisyonları, likidite karşılama oranı $(L K O)$ ile belirlenmektedir. Türk Bankacılık sektöründe yasal oran 2019 yılı itibarıyla 1/1 olarak düzenlenmiştir. Bankalar yasal LKO'nı sağladıktan sonra kredi oranlarını artırabilmek için istikrarlı kaynaklara yönelmektedir ve fonlama kaynaklarının istikrarı yatırımcılara yapılan sunumlarda önem kazanmaktadır. Alternatif kaynaklar, para piyasası işlemleri ve yurt dışı piyasalardan temin edilebilen borçlardır. Fonlama maliyeti hesaplamasında, mevduat faizinin ve alternatif kaynakların maliyetleri kadar kaynaklara ulaşım da önemli bir etkendir. Dolayısıyla mevduat faizlerinin diğer fon kaynaklarına göre oluşan maliyeti, bankaların ÇDY'e olan yöneliminde belirleyici bir unsurdur. Mevduatların aksine, teminat karşılığı fon sağlanan para piyasalarından borçlanılması bankaları likidite sıkıntısı içine düşürebilir.

Likit varlıklar/kısa süreli borçlar oranındaki bir birimlik artışın ÇDY'de yaptığı negatif etki doğrultusundaki bulgu, likit olmanın borçlanmaya duyulan gereksinim azaltmasının bir neticesidir. Çapacıoğlu ve Alper (2016), araştırmasına göre, K/M oranı ile mevduat faizleri arasındaki ilişki, mevduat yarışının yaşandığı dönemde güçlenmekte ve kısa vadeli likidite pozisyonu yasal eşiklere yakın olan bankaların mevduata olan talebini artırmaktadır. Kaldıraç 
(leverage) oranı sektörde döngüsel bir değişim göstermektedir ve borçlanma artışı bilanço büyümesinin en önemli nedenlerinden biridir. Modelin kaldıraç oranındaki bir birimlik artışa karşılık ÇDY'de 9 birimlik azalma ön görmesini, kaldıraç oranındaki artışın bilanço büyümesine olan etkisinin sonucu olarak değerlendirebiliriz. Diğer taraftan, bilanço genişlemesinin neden olduğu sermaye ihtiyacı, gerek sermaye yeterlilik rasyosunun tutturulması gerekse borçlanma kapasitesinin artırılabilmesi için yeni finansal kaynaklara olan bağımlılığı artırmaktadır.

Küresel finansal kriz sonrası gelişmekte olan ülkelerde finansal aracılar, yurt dışından düşük faiz oranları ile borçlanıp yurt içinde yerel para biriminden kredi vermeye yöneldiler. Bu durum bilançolarda para birimi uyumsuzluğu yaratmasının yanı sıra, küresel para sıkılaşmasının yaşandığ 1 piyasalarda likidite ihtiyacını arttırıcı rol oynamaktadır. Likit olma durumu, borç ödeyebilme gücüdür ve özellikle finansal döngülerin değiştiği dönemlerde önemi artmaktadır. Sermaye akımlarının geri çekilmesi neticesinde borçlanma faizlerinde görülen artışın ve borçlanma koşullarındaki zorlaşmanın neden olduğu likidite açığı, ülkenin para biriminde değer kaybına neden olmaktadır.

Yurt dışı borçlanmanın kurdaki artış nedeniyle öz sermaye erimesine neden olması, kaldıraç oranında kısıtlamaya gidilmesini gerektirmekte ve döviz borçlardaki büyüme kısır bir döngüye dönüşebilmektedir. Daha önce de değinildiği gibi, Cavallino ve Sandri (2018), bir makro model yardımı ile politika faizinde "genişletici alt sınır" kavramını incelemiş ve gelişmekte olan ekonomilerde bu sınırın daraltıcı sonuçlanmasını, bankaların sermaye kısıtlarına ve para birimi uyumsuzluğuna bağlamıştır. Ayrıca gelişmekte olan ülkelerde, sermaye piyasalarının derin olmaması riskin artması ile beraber likiditenin azalması neticesinde, varlık fiyatlarında düşüşü tetikleyerek, sermaye kayıplarının büyümesine neden olabilir. ÇDY özellikle yurt dışı borçlanma oranındaki artışı bir sinyali olmasının yanı sıra, kriz ortamında oluşan sermaye ihtiyacının karşılanması gerektiğinin de bir göstergesidir. Aksi durumda yurt dışı borçlanmaya devam edilse bile borçlanma faizindeki artış nedeniyle maliyetlerin yükselmesi sektörde ve ekonomide sistemik bir negatif etkiye dönüşebilir. Kur krizi modeli bulgularına göre, yurt dışı borçlanmanın toplam borçluluğa olan oranı bir birim arttığında, ÇDY'de 0,0178 birimlik artış göstermesi, ÇDY'deki artışın yurt dışı borçlanma artışının sinyal bir verisi olduğunu destekleyici yöndedir. (Bkz.Tablo 13)

Hahm vd. uyguladıkları panel probit regresyon modelde, ÇDY'in kur ve bankacılık krizlerini anlamada belirleyici gücü olduğu tespit edilmiştir. Kur krizi, ÇDY verisi ile \%1 oranında güçlü bir etkileşim göstermektedir. Dolayısıyla döviz cinsi borçlanmanın hem kur krizi hem de bankacılık krizi için güçlü bir sinyal olduğu vurgulanmaktadır. Özellikle yabancı para cinsinden borçlanmalarda ÇDY'in kredi/GSYİH rasyosuna göre çok daha açıklayıcı olduğunu, elde ettikleri sonuçlar doğrultusunda belirtmektedirler. Hahm vd.'nin kurdukları modele göre yabancı para cinsinden borç oranı kredi krizi ile \%1'lik bir etkileşim gösterirken, kredi/GSYIHH rasyosu açıklayıcı bir sonuç üretmemektedir.

Tablo 14. Sağlam Standart Hatalarla Bankacılık Krizinin Etkisini Yansıtan Rafine Modelin Tahmini

\section{Robust}

Bağımlı Değişken: ÇDY

\begin{tabular}{lllll} 
Bağımsız Değişkenler: & Katsayı & Std. Hata & t Testi & p Değeri \\
\hline ÇY & -3.43156 & 0.7562959 & -4.54 & 0.011 \\
Toplam Krediler & 4.27973 & 0.7592127 & 5.64 & 0.005 \\
Kredi/Mevduat & -2.83495 & 0.5583094 & -5.08 & 0.007
\end{tabular}


Kazaz, G. (2022). 9/1, 20-42

$\begin{array}{lllll}\text { ÇDY/ÇY } & 3.51743 & 0.7032569 & 5.00 & 0.007 \\ \text { ÇDY/Bilanço Toplamı } & -6.38490 & 0.4017932 & -15.89 & 0.000 \\ \text { cons } & 3.81813 & 0.7092938 & 5.38 & 0.006\end{array}$

R Kareler:

$\begin{array}{llll}\text { İçinde } & 0.8528 & \text { Sigma u } & 0.56984741 \\ \text { Arasında } & 0.9843 & \text { Sigma e } & 0.09126795 \\ \text { Genel } & 0.9126 & \text { Ro } & 0.97498967\end{array}$

Bulgular, bankacılık krizi açısından incelendiğinde, kredi büyümesi (Toplam Krediler) ve ÇDY/ÇY oranındaki artış, ÇDY ile pozitif bir etkileşim sergilemekte ve kredi büyümesinin ÇDY'le karşılandığını göstermektedir. Toplam kredilerdeki bir birimlik artış, ÇDY'de 4,28 birimlik artış ile sağlanabilmektedir. ÇDY'in ÇY'e bir birimlik artışı ise ÇDY'de 3.5 birimlik bir artış olmasını gerektirmektedir. Bu durum mevduat artışının yetersiz kalması durumunda bankaların alternatif kaynaklara yöneldiğini ve kredilerin ÇDY'le karşılandığını göstermektedir.

Kırılgan beşlide 2010-2019 yılları arasında ÇDY'in toplam borçluluk içindeki yüzdesi, Türkiye'de \%26'dan \%38'e, Endonezya'da \%11'den \%16'ya, Hindistan'da \%15'ten. \%17'ye yükselmiş, Güney Afrika'da \%44'ten \%36'ya, Brezilya'da ise, \%35'ten \%33'e düşmüştür. Döviz cinsi borçlanmanın toplam borçlanma içindeki yüzdesi ise, Türkiye'de $\% 36$ 'dan $\% 61$ 'e, Güney Afrika'da \%4'ten \%8'e, Brezilya'da \%11'den \%17'ye, Endonezya'da \%17'den \%20'ye ve Hindistan'da \%7'den \%8'e yükseldiği görülmektedir. Genel olarak yükseliş trendi olmasına karşın Türkiye'de çekirdek dışı borçlanmanın ve borçlanmanın içindeki dış borç payının dramatik bir artış göstererek genel trendden ayrıldığ tespit edilmektedir.

IMF (2009) raporu, finansal krizlerin yaşandığı yıllarda kredi/GSYİH rasyosunda görülen artışın kriz öncesi yıllarda da yüksek seyrettiğini vurgulamakta ve kredi büyümesi ile birlikte varlık fiyatlarındaki artışın nedeni olarak, varlıkların teminat için kullanılmasını göstermektedir. Kredi/mevduat rasyosu da krizin görüldüğü ve sonraki y1l \%120 oranını aşmaktadır. Yine benzer şekilde, bankaların ve özel sektörün döviz cinsi borçlanmasının krizden önceki yıllarda artmaya başlayarak, \%10'dan \%25'e yükseldiği tespit edilmiştir. Anundsen vd. (2014), çalışmasında bankaların krizden iki sene önceki dönemde döviz borçlarının mevduata oranı \%32'den, \%38'e yükselmesine karşın, krizi takip eden yılda hızlı bir şekilde düştüğünü vurgulamaktadır.

Türkiye'de 2010-2019 döneminde yabancı para cinsi borçlanmanın, mevduat toplamına olan oranının \%51'den, \%78'e tırmandığını görmekteyiz. 2019'da Brezilya'da \%27, Endonezya'da $\% 26$, Güney Afrika'da \%17 ve Hindistan'da \%10'a yükselmektedir. Genel trend yükseliş eğiliminde olmasına karşın Türkiye'deki dramatik yükselişin en önemli nedeninin tasarruf yetersizliği olduğu görülmektedir. Kredi artışına karşın mevduat artışının zayıf gelişimi, kredi artışının ekonomiye sağladığı katma değerin beklenen getiriyi yaratmadığını da düşündürmektedir.

Türk bankalarının dış borçlanma artışının diğer önemli bir nedeni de küresel likidite artışının borçlanma maliyetini düşürmüş olmasıdır. Artan ucuz likiditenin faiz oranlarını düşürmesi, TL mevduatların döviz cinsi mevduatlara kaymasına yol açarak dövize olan ihtiyacı artıran döngüyü beslemektedir. Bankalar, swap kanalı ile risklerini indirgeseler bile, artan riski özel sektöre ileterek, para ikamesi veya dolarizasyonun dramatik bir şekilde artmasında etken olabilir. Diğer taraftan, artan kredi arzının kalitesinin sorgulanmasıyla beraber şüpheli alacaklardaki artış oranı ve şeffaflık önem kazanmaktadır. Yurt dışı fon piyasaları, şeffaflık ve regülasyonlara olan uyumun değerlendirilmesi, fon kaynaklarının maliyetleri ve devamlılı̆̆ının sağlanmasında önem kazanmaktadır. 
Agenor ve Silva (2019), merkez bankalarının enflasyon hedeflerindeki başarıları kredibilite arttırıcı rol oynamakta ve piyasalara olan güveni artırmaktadır. Diğer yanda, borç toplamına karşın kaynakların yetersiz bulunması da kur riskini beslemektedir tespitini yapmaktadır. $\mathrm{Bu}$ açıdan değerlendirildiğinde, Türkiye CDS priminin normal kabul edilen 300 oranının üstünde hareket ettiği ve yurt dişı piyasaların daraldığı dönemlerde 500'lerin üstüne tırmandığ görülmektedir. Döviz kurundaki \%10'luk artış CDS priminde 50 baz puanlık artışa neden olmaktadır.

Orta gelir düzeyindeki ülkelerde (MIC) enflasyon oranını belirlemede kredi/GSYİH açığı " Basel Gap" rasyosu kullanılmaktadır. Politika faizini belirlerken, gerçekleşen kredi büyümesi ile beklenen büyüme oranı arasındaki farkın gözetilmesi, aşırı kredi büyümesinin ekonomide neden olduğu olumsuz sonuçların azaltılmasında etkili bir yol olacaktır. Kredi büyümesinin borç verme standartlarının gevşemesine neden olması, verilen kredilerin kalitesini düşürdüğü ve ekonomik daralmanın başladığı dönemde kırılmalara neden olduğu, birçok çalışmada tespit edilmektedir. Dolayısıyla kredi/GSYIH açığı rasyosu, döngüsel riskin anlaşılması ve finansal istikrara ulaşmak için sinyal niteliği taşımaktadır. Kredi/GSYIH, 2008-2017 döneminde MIC ülkelerinde \%75, gelişmiş ülkelerde \%190 olarak belirlenmiştir ve bu oran Türkiye dışındaki ülkelerde yıllar içinde önemli bir değişiklik göstermemesine karşın, Türkiye genel trendden ayrılmaktadır.

Mevduatta bir birimlik artışa karşın, ÇDY'de görülen üç birimlik azalış, mevduat artışının çekirdek dışı borçlanmaya duyulan ihtiyacı azaltmasının sonucudur. Farklı bir ifade ile mevduattaki bir birimlik açığın, üç birimlik ÇDY borçlanma ile karşılandığını söyleyebiliriz. Diğer yandan, bir birimlik kredi artışının dört birimlik ÇDY artışına neden olmasını, kredi mevduat rasyosu yüksekliğine işaret etmektedir. Bankaların merkez bankalarına yatırmak zorunda oldukları karşılıklar da, bir birimlik kredi için gereken mevduat oranını artırmaktadır. Krediler piyasa dinamiklerine bağlı olarak yeterli incelemeler yapılmadan verildiğinde, ayrılması gereken karşılık tutarlarındaki artış likit ve sermaye ihtiyacını artıracaktır.

Modelde, kredi/mevduat oranındaki bir birimlik artışa karşın ÇDY oranında 2,8 birimlik azalış görülmektedir. Artan kredi hacminin sermaye artırımı gerektirmesi, borçlanma oranında azalmaya neden olan önemli bir etkendir. Sermaye artırımı tercih edilmiyor ise, risk oranındaki

artış borçlanmayı daha pahalı hale getirerek ÇDY'de azalmaya neden olabilir. Artan risk, borçlanma maliyetini artırarak kârlılığı da olumsuz etkilemektedir. Bankaların, sermaye kısıtlarının izin verdiği sürece, ÇDY'e yönelmeleri sonucunda piyasada oluşan kümülatif risk ancak gecikmeli olarak izlenebilmektedir.

Toparlanacak olursa, elde edilen bulgular neticesinde, mevduat artışının veya tasarrufların yetersiz kalması durumunda kredi talebi ÇDY'le karşılanmakta ve bankalar çoğunlukla yurt dışı borçlanmaya yönelmektedir. Yurt dışı borçlanma artışının dolarizasyonu yani para ikamesini artırıcı etkisi MIC'de ülke paralarında değer kaybına ve borç toplamlarında artışa neden olmaktadır. Kurdaki değer kaybı ile oluşan dalgalanmanın CDS primlerinde de yükselişe neden olması, borçlanma maliyetlerini artırmasının yanı sıra borçlanmayı da zorlaştırarak likidite sıkıntısına sebep olan kısır bir döngüye yol açmaktadır.

\section{Sonuç ve Öneriler}

Gelişmekte olan ülkelerin bankacılık sektörünün genelinde, 2010 yılından beri çekirdek dış1 yurt dışı borçlanmada artış görülmektedir. Türkiye açısından da durum değişmemekte, ancak yurt dış1 borçlanmadaki artışa karşın istikrarlı bir ekonomik büyüme sağlanamamaktadır. Çalışmada panel veri modelleri kullanılarak Global Finansal Kriz" sonrası yaşanan finansal düzenlemelerin ve çekirdek dişı yükümlülüklerin bankacılık sektörüne olan etkileri ekonometrik analiz ile saptanmaya çalışılmıştır. Ülkemizin de içinde bulunduğu kırılgan beşli tabir edilen yükselen ekonomilerin çekirdek dışı yükümlülüklerin deki artışın bankacılık ve kur krizi ile olan ilişkisi sorgulanmaktadır. Bulgular; çekirdek dışı yükümlülükler deki artışın ekonomide kredi 
genişlemesinin öncü bir göstergesi olduğu ve yurt dışı borçlanmayı tetiklediği yönündedir. $\mathrm{Bu}$ etkileşim bankacılık sektörünün, finansal döngünün genişleme fazında kredi verme iştahını artırdığı ve mevduatın kredi ihtiyacını karşılamada yetersiz kaldığı dönemlerde, oluşan finansal açığı çekirdek dışı yükümlülüklere yönelerek tamamladığını göstermektedir. Borçlanma artış1 bilanço büyümesinin en önemli nedenlerinden biridir. Literatürdeki güncel çalışmaların bulgularıyla tutarlı şekilde, çekirdek dişı yükümlülüklerin kur ve bankacılık krizlerini anlamada belirleyici gücü olduğu tespit edilmiştir. Dolayısıyla döviz cinsi borçlanmanın hem kur krizi hem de bankacilık krizi için güçlü bir sinyal olduğu söylenebilir. Genel olarak gelişmekte olan ülkelerde ve özel olarak Kırılgan Beşlide borçlanmada yükseliş trendi olmasına karşın, Türkiye'de çekirdek dışı borçlanmanın ve borçlanmadaki dış borcun payının dramatik bir artış göstererek genel trendden ayrıldığı tespit edilmiştir. Kredi artışına karşın mevduat artışının zayıf gelişimi, kredi artışının ekonomiye sağladığı katma değerin beklenen getiriyi yaratamadığı ve gereken tasarrufların sağlanmadığını düşündürmektedir. Yurt dışı borçlanma artışının dolarizasyonu; yani para ikamesini artırıcı etkisi, Türk Lirasında değer kaybına ve borç toplamında artışa neden olmaktadır. Diğer taraftan, dış borç toplamına karşın, rezervlerin yetersiz bulunması kur riskini besleyerek kurda ani değişikliklere neden olabilmektedir. Kurdaki ani değişikliklerin enflasyon hedeflemesini zorlaştırması ise TCMB'nin, kredibilitesini zedeleyerek, yapılan açıklamalarla piyasaları yönlendirme gücünü zayıflatmaktadır. Oysa günümüzde merkez bankalarından beklenen en önemli piyasa müdahalesi, yapılan açıklamalarla ekonomik birimleri yönlendirebilme yetisidir. Bu yolla, para politikalarından fiyat istikrarı ve finansal istikrarın sağlanması beklenmektedir.

Basel III düzenlemeleri kapsamında kredi/GSYİH oranı ile bu oranın uzun vadeli eğilimi arasındaki fark olarak tanımlanan kredi/GSYİH açı̆̆ı dikkate alınmaya başlanmıştır. Rasyo takibi, finansal piyasaların yükseliş dönemlerinde sermaye oranını artırarak bankaların finansal krizlere karşı korunmasını hedeflemek ile beraber, finansal döngüden ziyade ekonomik döngüyü gözetmektedir. Rasyo, finansal krize karşı yumuşatıcı bir etki yaratsa da mevcut krizle mücadele konusunda yapıcılık göstermemektedir. Diğer yandan, likit olma durumu, verilen kredilerin teminatlandırılması, açık pozisyon büyüklüğü, borçlarını ödeme kabiliyeti gibi finansal yapılarındaki farklılık her bir kurum için ayrı ayrı dikkate alınmayarak, genel bir yaklaşım sürdürülmektedir. Bu açılardan, ÇDY büyüklüğünün takibi bankacılık sektörünün anlık finansal durumunu tespit ederek gerekli önlemleri saptamada daha kullanışlı bir veri setidir. ÇDY/GSYIHH oranı, verilen kredilerin ekonomiye yaptığı katkının ölçümlenmesinden farklı olarak, bankaların çekirdek tabir edilen yükümlülüklerinden fazla borçlanmasının ekonomiye olan katkısını anlamamıza da yardımcı olmaktadır. 


\section{Kaynakça}

Acharya, V., Mora, N. A. (2013). Crisis of Banks as Liquidity Providers. Journal of Finance NYU Working Paper, 2451/31364.

Agenor, P. R., Pereira S., Luiz, A. (2013). İntegrated İnflation Targeting - Another Perspective from the Developing World., Banco Central do Brasil Working Paper, 324: 4-15

Akdoğan, K., Yıldırım, D.B. (2014). None Core Liabilities as an indicator of Systemic Risk and a liquidity Stress Test Application on Turkish Banking System, Central Bank of Turkey Working Paper, 14.

Akyüz, Y. (2011). Küresel Kriz ve Yükselen Ekonomilerde Büyüme ve İstikrar: Çift Şeritli Yol mu, Yoksa Yolun Sonu mu? İktisat ve Toplum Dergisi, 13: 20-26.

Basten, C., Koch, C. (2015). Higher Bank Capital Requirements and Mortgage Pricing: Evidence from the Countercyclical Capital Buffer. BIS Working Paper Basel, 511.

Başç1, E., Kara H. (2011). Central Bank of Turkey Report.

Bernanke, B., Mihov, I. (2009). Deflation and Monetary Contraction in the Great Depression: An Analysis by Simple Ratios. Princeton University Press New York.

BIS Statistics. (2019). Kredi/GSYIH Rasyoları.

Binici, M. K. (2012). Is the Leverage of Turkish Bank Procyclical. TCMB Review, 12: 11-24

Borio, C., Drehman, M., Tsatsaronis K. (2012). Characterizing The Financial Cycle: Don't Lose Sight Of The Medium Term. BIS Working Paper Basel, 80.

Claessen, S., Ghost, S., Mihet, R. (2013). Macro-Prudential Policies to Mitigate Financial System Vulnerabilities. Journal of International Money and Finance, 39: 153-185

Drehmann, M., Tsatsaronis, K. (03-2014). The credit to GDP gap and countercyclical capital buffers: questions and answer, BIS Quarterly Review, 1-19.

Drehmann, M., Juselius, M. (2013). Evaluating Early Warning Indicators of Banking Crises. BIS Working Paper Basel, 421: 3-10.

Erdem, B., Özen, E., Ünalmış, İ. (2017). Are Macroprudential Policies Effective Tools Reduce Credit Growth in Emerging Markets? Central Bank of Turkey Review, 17/12.

Frankel, J., Rose, A. (2000). An Estimate of The Effect Of Common Currencies on Trade and Income. NBER Working Paper Cambridge, 7857.

Gasperini, G., Rixtel, A. (03-2013). Financial Crises and Bank Funding;Recent Experience in the Euro Area. BIS Working Paper Basel, 406: 10-25.

Hahm, H. J., Miskin, S. F., Shin, H. S., Shin, K. (2012). Macroprudential Policies in the Open Market. NBER Working Paper Cambridge, 17780:24-42.

Hahm, J. H., Shin, H. S., Shin, K. (2012). None-Core Bank Liabilities and Financial Vulnerability. NBER Working Paper Cambridge, 18428.

Hamann, F., Hernandez, R., Silva, L., Tenjo G F. ,(2014). Leverage Pro-Cyclicality and Bank Balance Sheet Colombia. Elsevier Doyma Economica, 32(73): 50-76.

Harutyunyan, A., Massara, A., Ugazio, G., Amidzic, G., Walton, R. (2015). Shedding Light on Shadow Banking. IMF Working Paper, 15/1.

Kara, H. (2016). A Brief Assessment of Turkey's Macroprudential Policy Approach 2011-2015. Central Bank of Turkey Review, 16/3: 85-92. 
Kılınç, Z., Karasoy, H., Yücel, E. (2013). None-core Liabilities and Credit Growth. Central Bank of Turkey Working Paper, 13-24.

Koo, R. (2011). The World in Balance Sheet Recession Causes, Cure and Politics. Real-World Economics Review, 58.

Kozanoğlu, H. (26.01.2021). Dünya Borç Krizi Yolda mı? BirGün Gazetesi.

Mendoza, G. E., Terrones, E. M. (2012). An Anatomy of Credit Booms and Their Demise, NBER Working Paper Cambridge, 18379.

Miskin, F. (2016). The Economics of Money, Banking and Financial Markets. Global Edition, (Cilt 11). New York, Columbia University.

Reyna, O. T. (2007). Panel Data Analysis Fixed and Random Effects using Stata. Princeton University, http://dss.princeton.edu./training/

Roubini, N. (2018). Kriz Ekonomisi (2. Bask1). İstanbul: Pegasus Yayınevi.

Sang, A. A., Yoo, C. C., Hong, C. (2012). Managing Non-Core Liabilities and Leverage of the Banking System: A Building Block for Macroprudential Policy Making in Korea. IMF Working Paper, 12/27.

Stiglitz, E. J., Greenwald, C. B. (2003). Towards a New Paradigm in Monetary Economics. (1. Bask1). İngiltere: Cambridge University Press.

Tunay, K. B., Tunay, N. (2013). Finansal Krizler ve Sigortacılık: Deneysel Bulguların Işığında Türk Sigorta Sektörüne Dair değerlendirmeler, Marmara Üniversitesi İBB Dergisi, XXXV(II), 91-95.

Y1lmaz, E. (2020). How The Credits Dollarize? The Role of Firms Natural Hedges, Banks Core and None-Core Liabilities. Central Bank of Turkey Working Paper, 201/1.

Yılmaz, E., Süslü, B. (2016). Turkish None-Core Liabilities, South Eastern Europe Journal of Economies, 1:76-90. 
Tanımsal İstatistikler

\begin{tabular}{|c|c|c|c|c|c|}
\hline Vari able & Obs & Mean & Std. Dev. & $\mathrm{Mn}$ & $\operatorname{Max}$ \\
\hline $\begin{array}{r}\text { grup } \\
\text { zanan } \\
\text { ncl usd } \\
\text { cust depusd } \\
\text { bl st usd } \\
\text { t ot I onusd } \\
\text { I oandepoz }\end{array}$ & $\begin{array}{l}50 \\
50 \\
50 \\
50 \\
50 \\
50 \\
50\end{array}$ & $\begin{array}{r}2014.5 \\
12.09036 \\
13.11364 \\
13.64254 \\
13.22613 \\
1.17191\end{array}$ & $\begin{array}{r}1.428571 \\
2.901442 \\
.9155709 \\
.8349775 \\
.7066398 \\
.6233327 \\
.389924\end{array}$ & $\begin{array}{r}1 \\
2010 \\
10.2563 \\
11.6589 \\
12.5714 \\
12.2011 \\
.7754\end{array}$ & $\begin{array}{r}2019 \\
13.3222 \\
14.4024 \\
14.6991 \\
14.2306 \\
2.0845\end{array}$ \\
\hline $\begin{array}{r}\text { cust dept I oan } \\
\text { ncl cdepoz } \\
\text { ncl bl sheet } \\
\text { capi treser v } \\
\text { I vg } \\
\text { I i quasset s - b } \\
\text { npl t ot I oan }\end{array}$ & $\begin{array}{l}50 \\
50 \\
50 \\
50 \\
50 \\
50 \\
50\end{array}$ & $\begin{array}{r}928822 \\
.397946 \\
220714 \\
14.91951 \\
.897554 \\
74.346 \\
3.812\end{array}$ & $\begin{array}{r}.2373879 \\
.182294 \\
.0758894 \\
3.047901 \\
.0293505 \\
70.09297 \\
1.949949\end{array}$ & $\begin{array}{r}.4797 \\
.0002 \\
.0001 \\
11.8477 \\
.8309 \\
22.3 \\
1.7\end{array}$ & $\begin{array}{r}1.2896 \\
.7896 \\
.326 \\
20.9482 \\
.933 \\
242\end{array}$ \\
\hline $\begin{array}{r}\text { roa } \\
\text { roe } \\
\text { f or gcur enc }-b \\
\text { cr edi t gdpgap } \\
\text { net openpoz }-1 \\
\text { banki ngcri } \sim 5 \\
\text { cur rencycr } \sim 5\end{array}$ & $\begin{array}{l}50 \\
50 \\
50 \\
50 \\
50 \\
50 \\
50\end{array}$ & $\begin{array}{r}1.668 \\
16.224 \\
19.918 \\
2.724 \\
1.7828 \\
.1 \\
.14\end{array}$ & $\begin{array}{r}7396745 \\
5.357602 \\
15.96906 \\
6.376665 \\
2.657929 \\
.3030458 \\
3505098\end{array}$ & $\begin{array}{r}0 \\
-.2 \\
4.1 \\
-9.4 \\
-3.5 \\
0 \\
0\end{array}$ & $\begin{array}{r}3 \\
25 \\
60 \\
13 \\
8\end{array}$ \\
\hline $\begin{array}{l}\text { _est_r andom } \\
\text { est_fi xed }\end{array}$ & $\begin{array}{l}50 \\
50\end{array}$ & $\begin{array}{l}1 \\
1\end{array}$ & $\begin{array}{l}0 \\
0\end{array}$ & 1 & \\
\hline
\end{tabular}




\section{Korelasyon Katsayıları}

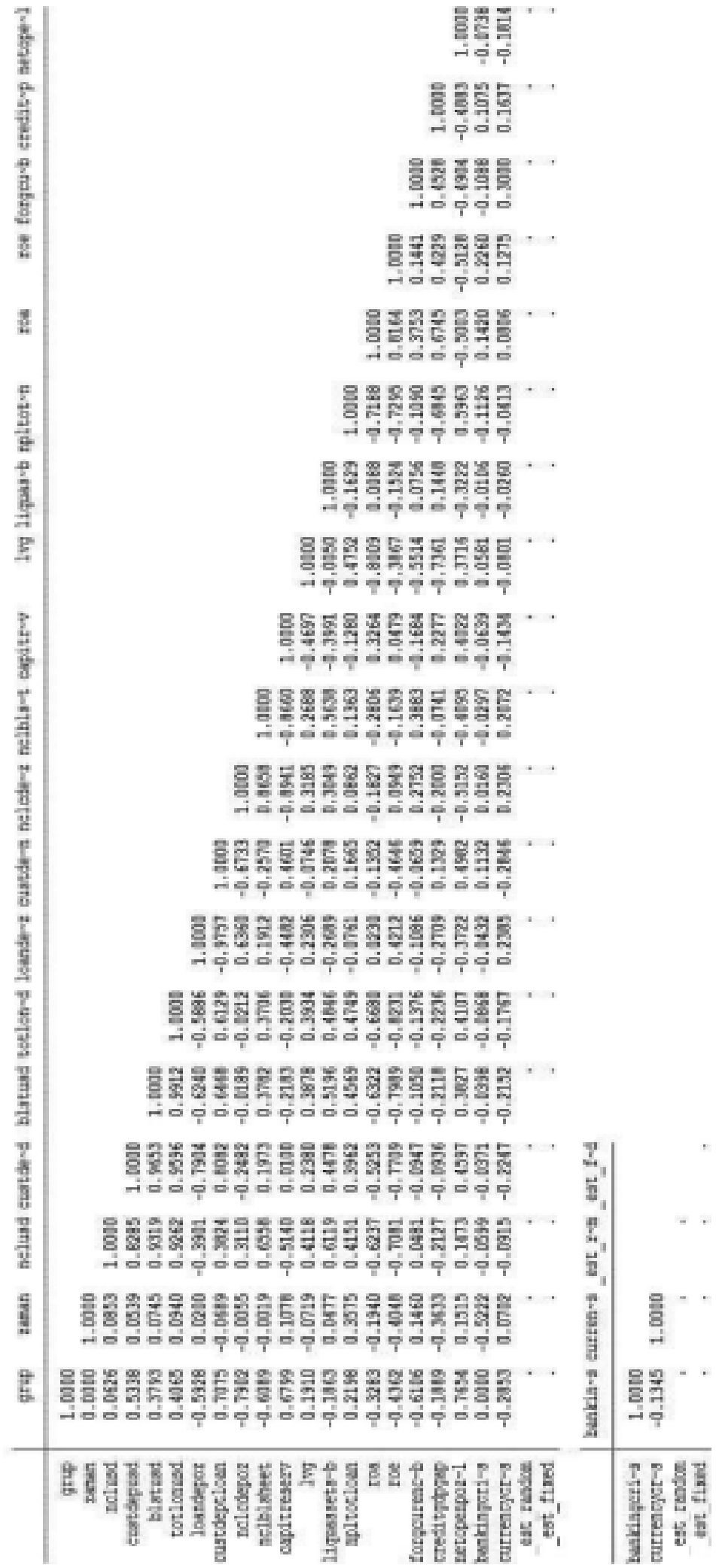

